\title{
Inter-generic relationships of the crows, jays, magpies and allied groups (Aves: Corvidae) based on nucleotide sequence data
}

\author{
Per G. P. Ericson, Anna-Lee Jansén, Ulf S. Johansson and Jan Ekman
}

\begin{abstract}
Ericson, P. G. P., Jansén, A.-L., Johansson, U. S. and Ekman, J. 2005. Inter-generic relationships of the crows, jays, magpies and allied groups (Aves: Corvidae) based on nucleotide sequence data. - J. Avian Biol. 36: 222-234.
\end{abstract}

\begin{abstract}
Phylogenetic relationships were studied based on DNA sequences obtained from all recognized genera of the family Corvidae sensu stricto. The aligned data set consists $2589 \mathrm{bp}$ obtained from one mitochondrial and two nuclear genes. Maximum parsimony, maximum-likelihood, and Bayesian inference analyses were used to estimate phylogenetic relationships. The analyses were done for each gene separately, as well as for all genes combined. An analysis of a taxonomically expanded data set of cytochrome $b$ sequences was performed in order to infer the phylogenetic positions of six genera for which nuclear genes could not be obtained. Monophyly of the Corvidae is supported by all analyses, as well as by the occurrence of a deletion of $16 \mathrm{bp}$ in the $\beta$-fibrinogen intron in all ingroup taxa. Temnurus and Pyrrhocorax are placed as the sister group to all other corvids, while Cissa and Urocissa appear as the next clade inside them. Further up in the tree, two larger and well-supported clades of genera were recovered by the analyses. One has an entirely New World distribution (the New World jays), while the other includes mostly Eurasian (and one African) taxa. Outside these two major clades are Cyanopica and Perisoreus whose phylogenetic positions could not be determined by the present data. A biogeographic analysis of our data suggests that the Corvidae underwent an initial radiation in Southeast Asia. This is consistent with the observation that almost all basal clades in the phylogenetic tree consist of species adapted to tropical and subtropical forest habitats.
\end{abstract}

P. G. P. Ericson (correspondence), Department of Vertebrate Zoology and Molecular Systematics Laboratory, Swedish Museum of Natural History, Box 50007, SE-104 05 Stockholm, Sweden. E-mail: per.ericson@nrm.se. A.-L. Jansén, Department of Vertebrate Zoology, Swedish Museum of Natural History, Box 50007, SE-104 05 Stockholm, Sweden. U. S. Johansson, University of Chicago, Department of Ecology and Evolution, 1101 East 57th Street, Chicago, IL 60637, USA. J. Ekman, Evolutionary Biology Centre, Uppsala University, Norbyvägen 18D, SE-752 36 Uppsala, Sweden.

The family Corvidae (sensu Morony et al. 1975) consists of more than 100 species of crows, jays, magpies and allies, arranged in 25 genera (Cissilopha is here considered a subgenus of Cyanocorax following Madge and Burn 1994). Sibley and Monroe (1990) called this group Corvini, while their Corvidae was a taxonomically much larger group that included also many other traditional families, e.g., vangas, drongos, whistlers, orioles and monarch flycathchers. The Corvidae sensu stricto has a worldwide distribution, and the family is represented in almost all habitats. Corvids are renowned for an unusual intelligence among birds and a wide range of fascinating behavioural adaptations have been documented in the group, including cooperative breeding. Corvids thus attract considerable attention from general biologists, and are favoured study objects of many ethologists and ecologist. Despite this broad interest the patterns of evolution and the phylogenetic relationships of the Corvidae are inadequately known. The early history of the classification of the Corvidae has been summarized elsewhere (Goodwin 1976, Hope 1989, and Sibley and Ahlquist 1990) and here we will focus only on previous 
ideas about the higher-level relationships within the group.

Most corvid genera are well defined and little controversy exists about their monophyly. Most taxonomists acknowledge the traditional delimitations of genera (e.g., Sibley and Monroe 1990), although Amadon (1944) argued for reducing the number of genera of New World jays and Southeast Asian magpies and treepies. Certain monophylethic groups of corvid genera are also widely recognized. The largest of these consists of the five genera of New World jays (Calocitta, Cyanocorax, Cyanolyca, Gymnorhinus and Psilorhinus), and it has been suggested that the Holarctic Perisoreus and the Palearctic Garrulus are closely related to this group. Another assumingly monophyletic group consists of Nucifraga and the species-rich genus Corvus. Also the Southeast Asian magpies and treepies (Cissa, Dendrocitta, Temnurus and Urocissa) are often regarded to form a monophyletic group of genera to which Platysmurus and sometimes Cyanopica and Pica have been added.

Most proposals about higher-level relationships among corvids have been based on studies in comparative anatomy (e.g., Amadon 1944). The few phylogenetic analyses of intergeneric relationships that exist mostly utilize DNA sequence data obtained from mitochondrial genes (Espinosa de los Monteros and Cracraft 1997, Cibois and Pasquet 1999, Saunders and Edwards 2000), and only one is based on morphology (Hope 1989). Also, molecular and morphological informations are rarely analysed together, with the exception of an analysis of the New World jays by Espinosa de los Monteros and Cracraft (1997) where parts of Hope's morphological data set were added to their cytochrome $b$ data set.

It has long been discussed which taxa constitute the earliest radiation within the Corvidae, and both the crows and the jays have been suggested based on their possession of purportedly primitive characters. On the other hand, crows and jays are not supposed to be particularly close to each other (Goodwin 1976). Furthermore, osteological data supports neither crows nor jays as basal radiations of corvids, but places the Southeast Asian magpies and treepies in this position (Hope 1989). Yet another hypothesis places the choughs (Pyrrhocorax) as the most basal branch of the family based on an analysis of cytochrome $b$ sequence data (Cibois and Pasquet 1999). However, these authors noted that the phylogenetic relationships suggested by the cytochrome $b$ data set were very sensitive to which model for nucleotide substitutions and weighting scheme were employed, as well as to which analytical method was used.

Herein we present a hypothesis of the intergeneric relationships of the Corvidae based on DNA sequence data obtained from one mitochondrial, protein-coding (cytochrome $b$ ) gene and two introns positioned in the nuclear myoglobin and $\beta$-fibrinogen genes, respectively. The occurrence of the three loci in three linkage groups is based on their known positions in the human genome. This means that they have evolved independently, thus providing three independent estimates of the true branching patterns within the Corvidae. In addition to this large data set, we also studied a cytochrome $b$ data set consisting of representatives from all genera of corvids. In order to estimate the phylogenetic position of the six genera for which we were unable to sequence the nuclear markers, we also studied a data set including only cytochrome $b$ but representing all genera of corvids.

\section{Materials and methods}

\section{Examined taxa and choice of outgroups}

A total of 32 species representing 23 genera included in the Corvidae have been included in the analyses (Table 1). These taxa represent all genera traditionally included in this family (Madge and Burn 1994), with the exception of Pseudopodoces and Platylophus. Pseudopodoces has recently been shown to be a ground-adapted tit (Paridae) based on morphological and molecular data (James et al. 2003), and the corvid affinity of Platylophus has long been questioned (Amadon 1944, Goodwin 1976). Sibley and Monroe (1990), based on DNADNA hybridization data, retained Platylophus in their Corvini (i.e., Corvidae in traditional classifications), but both Clench (1985) and Hope (1989), based on their respective analyses of the pterylosis and osteology, concluded that it is not a corvid. This is also confirmed from an analysis of mitochondrial and nuclear sequence data (P. G. P. Ericson pers. obs.). Pseudopodoces and Platylophus are thus both excluded from the present analysis. It should also be pointed out that the genus Psilorhinus often is synonymized with Cyanocorax (AOU 1998), a combination consistent with the present analysis.

It was not possible to amplify nuclear DNA from the study skin samples. We therefore conducted analyses on two different data sets. The first consists of data from both mitochondrial and nuclear genes obtained from fresh samples. A total of 18 corvid species representing 17 genera are included in this data set. We also investigated a taxonomically more inclusive data set comprising 31 species representing all recognized corvid genera. Only cytochrome $b$ sequences were included in this data set.

Three outgroups were used: Lanius (Laniidae) represented by L. ludovicianus and L. collurio, Vireo olivaceus (Vireonidae) and Epimachus albertisi (Paradisaeidae). The outgroups were chosen to represent close relatives of the corvid clade as suggested by analyses of DNA-DNA hybridisation (Sibley and Ahlquist 1990) and DNA sequences (P. G. P. Ericson pers. obs.). Due to problems 
Table 1. The studied species (taxonomy follows Madge and Burn 1994). FMNH: Field Museum of Natural History, Chicago; MNHN: Muséum National d'Histoire Naturelle (Paris); NRM: Swedish Museum of Natural History; UWBM: Burke Museum of Natural History and Culture (Seattle). References: 1: Espinosa de los Monteros and Cracraft (1997), 2: Cibois and Pasquet (1999), 3: Helm-Bychowski and Cracraft (1993), 4: Nunn and Cracraft (1996), 5: Cracraft and Feinstein (2000), 6: Cicero and Johnson (1998), 7: Härlid and Arnason (1999), 8: Ericson et al. (2002a), and 9: Ericson and Johansson (2003).

\begin{tabular}{|c|c|c|c|c|c|}
\hline Species & Vernacular name & $\begin{array}{c}\text { Gene } \\
\text { sequenced }\end{array}$ & Source & Voucher no. & GenBank no. \\
\hline $\begin{array}{l}\text { Aphelocoma } \\
\text { coerulescens }\end{array}$ & Scrub jay & $\begin{array}{l}\text { myoglobin, } \\
\beta \text {-fibrinogen }\end{array}$ & muscle & FMNH 333861 & AY395580, AY395598 \\
\hline $\begin{array}{l}\text { Calocitta } \\
\text { formosa }\end{array}$ & White-throated magpie-jay & $\begin{array}{l}\text { cytochrome } b \\
\text { myoglobin, } \\
\beta \text {-fibrinogen }\end{array}$ & muscle & FMNH 393683 & $\begin{array}{l}\text { U77335 (ref. 1) } \\
\text { AY395581, AY395599 }\end{array}$ \\
\hline $\begin{array}{l}\text { Cissa } \\
\quad \text { chinensis }\end{array}$ & Green magpie & $\begin{array}{l}\text { cytochrome } b \\
\text { myoglobin, } \\
\beta \text {-fibrinogen }\end{array}$ & muscle & MNHN uncat. & $\begin{array}{l}\text { U77336 (ref. 1) } \\
\text { AY395582, AY395600 }\end{array}$ \\
\hline Corvus corax & Common raven & cytochrome $b$ & & & U86031 (ref. 2) \\
\hline Corvus corone cornix & Hooded crow & cytochrome $b$ & & & U86032 (ref. 2) \\
\hline $\begin{array}{l}\text { Corvus } \\
\quad \text { coronoides }\end{array}$ & Australian raven & cytochrome $b$ & & & AF197837 (ref. 5) \\
\hline $\begin{array}{l}\text { Corvus } \\
\text { frugilegus }\end{array}$ & Rook & $\begin{array}{l}\text { myoglobin, } \\
\beta \text {-fibrinogen }\end{array}$ & muscle & NRM 986396 & AY395583, AY395601 \\
\hline $\begin{array}{l}\text { Corvus } \\
\quad \text { monedula }\end{array}$ & Western jackdaw & $\begin{array}{l}\text { cytochrome } b \\
\text { myoglobin, } \\
\beta \text {-fibrinogen }\end{array}$ & muscle & NRM 986450 & $\begin{array}{l}\text { NC } 002069 \text { (ref. 7) } \\
\text { AY395584, AY395602 }\end{array}$ \\
\hline $\begin{array}{l}\text { Crypsirina } \\
\text { temia }\end{array}$ & Racket-tailed treepie & $\begin{array}{l}\text { cytochrome } b \\
\text { cytochrome } b\end{array}$ & study skin & NRM 568802 & $\begin{array}{l}\text { U86033 (ref. 2) } \\
\text { AY395618 }\end{array}$ \\
\hline Cyanocitta cristata & Blue jay & $\begin{array}{l}\text { myoglobin, } \\
\beta \text {-fibrinogen }\end{array}$ & muscle & FMNH 356957 & AY395585, AY395603 \\
\hline Cyanocorax chrysops & Plush-crested jay & $\begin{array}{l}\text { cytochrome } b \\
\text { myoglobin, } \\
\beta \text {-fibrinogen }\end{array}$ & muscle & NRM 956615 & $\begin{array}{l}\text { X74258 (ref. 3) } \\
\text { AY395586, AY395604 }\end{array}$ \\
\hline Cyanolyca viridicyana & Black-collared jay & $\begin{array}{l}\text { cytochrome } b \\
\text { cytochrome } b\end{array}$ & & & $\begin{array}{l}\text { U77334 (ref. 1) } \\
\text { U77333 (ref. 1) }\end{array}$ \\
\hline $\begin{array}{l}\text { Cyanopica } \\
\text { cyana }\end{array}$ & Azure-winged magpie & $\begin{array}{l}\text { myoglobin, } \\
\beta \text {-fibrinogen }\end{array}$ & muscle & UWBM 59859 & AY395587, AY395605 \\
\hline Dendrocitta formosae & Grey treepie & $\begin{array}{l}\text { cytochrome } b \\
\text { cytochrome } b\end{array}$ & $\begin{array}{l}\text { study skin } \\
\text { study skin }\end{array}$ & $\begin{array}{l}\text { NRM } 568808 \\
\text { NRM } 568803\end{array}$ & $\begin{array}{l}\text { AY395619 } \\
\text { AY395620 }\end{array}$ \\
\hline $\begin{array}{l}\text { Garrulus } \\
\quad \text { glandarius }\end{array}$ & Eurasian jay & cytochrome $b$ & & & U86034 (ref. 2) \\
\hline Garrulus lidthi & Lidthi's jay & $\begin{array}{l}\text { myoglobin, } \\
\beta \text {-fibrinogen }\end{array}$ & muscle & MNHN uncat. & AY395588, AY395606 \\
\hline $\begin{array}{l}\text { Gymnorhinus } \\
\text { cyanocephala }\end{array}$ & Pinyon jay & $\begin{array}{l}\text { cytochrome } b \\
\text { myoglobin, } \\
\beta \text {-fibrinogen }\end{array}$ & muscle & FMNH 334283 & $\begin{array}{l}\text { U86035 (ref. 2) } \\
\text { AY395589, AY395607 }\end{array}$ \\
\hline $\begin{array}{l}\text { Nucifraga } \\
\quad \text { caryocatactes }\end{array}$ & Spotted nutcracker & $\begin{array}{l}\text { cytochrome } b \\
\text { myoglobin, } \\
\beta \text {-fibrinogen }\end{array}$ & muscle & NRM 976114 & $\begin{array}{l}\text { U77332 (ref. 1) } \\
\text { AY395590, AY395610 }\end{array}$ \\
\hline $\begin{array}{l}\text { Perisoreus } \\
\quad \text { canadensis }\end{array}$ & Grey jay & $\begin{array}{l}\text { cytochrome } b \\
\text { cytochrome } b\end{array}$ & & & $\begin{array}{l}\text { U86041 (ref. 2) } \\
\text { U77331 (ref. 1) }\end{array}$ \\
\hline $\begin{array}{l}\text { Perisoreus } \\
\quad \text { infaustus }\end{array}$ & Siberian jay & $\begin{array}{l}\text { myoglobin, } \\
\beta \text {-fibrinogen }\end{array}$ & muscle & NRM 976543 & AY395591, AY395608 \\
\hline $\begin{array}{l}\text { Perisoreus } \\
\quad \text { internigrans }\end{array}$ & Sichuan jay & $\begin{array}{l}\text { cytochrome } b \\
\text { cytochrome } b\end{array}$ & study skin & NRM 568809 & $\begin{array}{l}\text { U86042 (ref. 2) } \\
\text { AY395621 }\end{array}$ \\
\hline Pica pica & Magpie & $\begin{array}{l}\text { myoglobin, } \\
\beta \text {-fibrinogen }\end{array}$ & muscle & NRM 986309 & AY395592, AY395609 \\
\hline $\begin{array}{l}\text { Platysmurus } \\
\text { leucopterus }\end{array}$ & Black magpie & $\begin{array}{l}\text { cytochrome } b \\
\text { cytochrome } b\end{array}$ & study skin & NRM 568801 & $\begin{array}{l}\text { U86036 (ref. 2) } \\
\text { AY395622 }\end{array}$ \\
\hline $\begin{array}{l}\text { Podoces } \\
\quad \text { biddulphi }\end{array}$ & Xinjiang ground-jay & cytochrome $b$ & study skin & NRM 568806 & AY395623 \\
\hline $\begin{array}{l}\text { Podoces } \\
\quad \text { hendersoni }\end{array}$ & Henderson's ground-jay & $\begin{array}{l}\text { myoglobin, } \\
\beta \text {-fibrinogen }\end{array}$ & muscle & UWBM 57967 & AY395593, AY395611 \\
\hline $\begin{array}{l}\text { Psilorhinus morio } \\
\text { Ptilostomus afer }\end{array}$ & $\begin{array}{l}\text { Brown jay } \\
\text { Piapiac }\end{array}$ & $\begin{array}{l}\text { cytochrome } b \\
\text { cytochrome } b \\
\text { myoglobin, } \\
\beta \text {-fibrinogen }\end{array}$ & $\begin{array}{l}\text { study skin } \\
\text { study skin } \\
\text { muscle }\end{array}$ & $\begin{array}{l}\text { NRM } 568804 \\
\text { NRM } 568805 \\
\text { MNHN uncat. }\end{array}$ & $\begin{array}{l}\text { AY395624 } \\
\text { AY395625 } \\
\text { AY395594, AY395613 }\end{array}$ \\
\hline Pyrrhocorax graculus & Yellow-billed chough & $\begin{array}{l}\text { cytochrome } b \\
\text { cytochrome } b\end{array}$ & & & $\begin{array}{l}\text { U86040 (ref. 2) } \\
\text { U86043 (ref. 2) }\end{array}$ \\
\hline $\begin{array}{l}\text { Pyrrhocorax } \\
\text { pyrrhocorax }\end{array}$ & Red-billed chough & $\begin{array}{l}\text { myoglobin, } \\
\beta \text {-fibrinogen } \\
\text { cytochrome } b\end{array}$ & muscle & UWBM 58057 & $\begin{array}{l}\text { AY395595, AY395612 } \\
\text { U86044 (ref. 2) }\end{array}$ \\
\hline
\end{tabular}


Table 1 (Continued)

\begin{tabular}{|c|c|c|c|c|c|}
\hline Species & Vernacular name & $\begin{array}{c}\text { Gene } \\
\text { sequenced }\end{array}$ & Source & Voucher no. & GenBank no. \\
\hline $\begin{array}{l}\text { Temnurus } \\
\text { temnurus }\end{array}$ & Ratchet-tailed treepie & $\begin{array}{l}\text { myoglobin, } \\
\beta \text {-fibrinogen }\end{array}$ & muscle & NRM 947306 & AY395596, AY395614 \\
\hline $\begin{array}{l}\text { Urocissa } \\
\quad \text { erythrorhyncha }\end{array}$ & Blue magpie & $\begin{array}{l}\text { cytochrome } b \\
\text { myoglobin, } \\
\beta \text {-fibrinogen } \\
\text { cytochrome } b\end{array}$ & $\begin{array}{l}\text { study skin } \\
\text { blood }\end{array}$ & $\begin{array}{l}\text { NRM } 568807 \\
\text { MNHN uncat. }\end{array}$ & $\begin{array}{l}\text { AY395626 } \\
\text { AY395597, AY395615 } \\
\text { U86038 (ref. 2) }\end{array}$ \\
\hline $\begin{array}{l}\text { Zavattariornis stresemanni } \\
\text { Epimachus } \\
\quad \text { albertisi }\end{array}$ & $\begin{array}{l}\text { Stresemann's bush-crow } \\
\text { Black-billed sicklebill }\end{array}$ & $\begin{array}{l}\text { cytochrome } b \\
\text { myoglobin, } \\
\beta \text {-fibrinogen } \\
\text { cytochrome } b\end{array}$ & $\begin{array}{l}\text { study skin } \\
\text { muscle }\end{array}$ & $\begin{array}{l}\text { NRM } 552443 \\
\text { MV C148 }\end{array}$ & $\begin{array}{l}\text { AY395627 } \\
\text { AY064735 (ref. 8), } \\
\text { AY395616 } \\
\text { U15205 (ref. 4) }\end{array}$ \\
\hline Lanius collurio & Red-backed shrike & $\begin{array}{l}\text { myoglobin, } \\
\beta \text {-fibrinogen }\end{array}$ & muscle & NRM 986403 & $\begin{array}{l}\text { AY228328 (ref. 9), } \\
\text { AY395617 }\end{array}$ \\
\hline $\begin{array}{l}\text { Lanius ludovicianus } \\
\text { Vireo cassinii }\end{array}$ & $\begin{array}{l}\text { Loggerhead shrike } \\
\text { Red-eyed vireo }\end{array}$ & $\begin{array}{l}\text { cytochrome } b \\
\text { cytochrome } b\end{array}$ & & & $\begin{array}{l}\text { X74259 (ref. 3) } \\
\text { AF081990 (ref. 6) }\end{array}$ \\
\hline
\end{tabular}

in sequencing nuclear genes from our sample of Vireo olivaceus, only Lanius and Epimachus were used as outgroups in the analyses of the nuclear data sets.

\section{Laboratory procedures}

Blood and tissue samples were obtained from the collections at the Swedish Museum of Natural History, Muséum National d'Histoire Naturelle (Paris), the Burke Museum of Natural History and Culture (Seattle), and the Field Museum of Natural History (Chicago). As no blood or tissue samples of the genera Crypsirina, Cyanolyca, Dendrocitta, Platysmurus, Psilorhinus and Zavattariornis could be located, we instead extracted DNA from museum study skins for these taxa. Although the nuclear introns failed to amplify, the cytochrome $b$ gene could be sequenced from the study skins.

All extractions were carried out using the QIAamp ${ }^{\mathrm{TM}}$ DNA Mini Kit (QIAGEN $\left.{ }^{\circledR}\right)$ following the manufacturer's instructions. Genomic DNA was prepared from tissue for all taxa except Urocissa for which blood was used. From the study skins the DNA was extracted from small pieces $\left(2-3 \mathrm{~mm}^{3}\right)$ of the foot papillae. After being cut from the study skins the samples were temporarily placed in ethanol. After digestion in Proteinase K for 24 $\mathrm{h}$, DNA was extracted through the QIAamp ${ }^{\mathrm{TM}}$ tissue extraction kit (QIAGEN ${ }^{\circledR}$ ) as described by Mundy et al. (1997). The DNA was degraded in all samples and several primers were used to amplify and sequence shorter segments of cytochrome $b$ (Table 2).

The protocol of Ericson et al. (2002a) was used for the amplification of cytochrome $b$ from fresh material. No stop codons or non-coding regions, indicating the presence of nuclear pseudogenes, were observed in the sequences. $924 \mathrm{bp}$ of cytochrome $b$ were selected for analysis, corresponding to the region between positions 14992 to 15915 in the chicken mitochondrial genome (Desjardins and Morais 1990). For several taxa cytochrome $b$ sequences were obtained from GenBank (Table 1).

An approximately 700 bp long fragment of the myoglobin gene was amplified using the protocol of Ericson (2002a) and Irestedt et al. (2002). The amplified fragment corresponds to the entire intron 2 and $13 \mathrm{bp}$ and $10 \mathrm{bp}$ of the flanking second and third exons, respectively. The maximum length of the intron 2 of the myoglobin gene was 696 bp (observed in most ingroup taxa) and the minimum length was $670 \mathrm{bp}$ (in Lanius).

PCR-amplification and sequencing of the $\beta$-fibrinogen gene following Prychitko and Moore (1997) resulted in an approximately $900 \mathrm{bp}$ long fragment of intron 7 . The sequencing posed some problems for Corvus frugilegus of which seven basepairs in the beginning of the sequence could not be determined and these were coded as missing in the analyses. The minimum length of the $\beta$ fibrinogen intron 7 was 862 bp (Urocissa) and the maximum length was 922 bp (Lanius).

Table 2. Primer sequences for amplifying and sequencing shorter segments of cytochrome $b$ from museum study skins.

\begin{tabular}{llc}
\hline Name & \multicolumn{1}{c}{ Primer sequence $\left(5^{\prime}\right.$ to $\left.3^{\prime}\right)$} & Sequencing direction \\
\hline L14850 & AAC ATC TCC GCT GGA TGA AAC TTC GGA TC & Forward \\
L413 & AAT ATC CTT CTG AGG AGC TAC AGT CAT & Forward \\
L658 & CCA TTC CAC CCC TAC TAC TCC ATC AAA GA & Forward \\
L799 & CCT CAC ATC AAA CCA GA TGA TAC TTC C & Forward \\
H454 & TGT TTG TCC AAT GTA TGG GAT TGC TGA & Reverse \\
H598 & GTT GTT TGA GCC TGT TTC GTG TAG GAA & Reverse \\
H658 & TCT TTG ATG GAG TAG TAG GGG TGG AAT GG & Reverse \\
H814 & ATG GCG TAT GCA AAT AGG AAG TAT CAT TC & Reverse \\
H952 & AAT AGG ATT TGT GAT AGG GGT CGG AA & Reverse \\
\hline
\end{tabular}




\section{Alignment and phylogenetic analyses}

The sequences could readily be aligned by eye using MegAlign $^{\text {TM }}$ (DNASTAR ${ }^{\circledR}$ ). The aligned sequences include 2589 base pairs (bp) of homologous nucleotides, of which $924 \mathrm{bp}$ derive from the cytochrome $b$ gene, 721 bp from myoglobin intron 2 and flanking regions, and $944 \mathrm{bp}$ from $\beta$-fibrinogen intron 7. There were a few indels observed in the aligned sequences. In the myoglobin intron, three autapomorphic indels were observed in the ingroups after alignment. For $\beta$-fibrinogen, all ingroup taxa share a $16 \mathrm{bp}$ deletion relative to the outgroups. Urocissa further showed two major deletions (17 bp and $12 \mathrm{bp}$, respectively), but only a few additional (all autapomorphic) indels were observed in the ingroup. The alignments of the myoglobin and $\beta$-fibrinogen data sets are available as PopSets in GenBank. Nucleotide frequencies, uncorrected sequence divergences (p-distances) and inferred numbers of transitions and transversions were determined with Mega 1.0 (Kumar et al. 1993).

Both parsimony and maximum-likelihood analyses were performed in PAuP* 4.0b10 (Swofford 1998). The heuristic search option with TBR-branch swapping, and ten random additions of taxa were used in the parsimony analysis. These analyses were done for the genes independently, and for all genes combined. The cytochrome $b$ gene was analysed with both all codon positions unweighted, and after removal of transition substitutions at third codon positions. Nodal supports in the parsimony analyses were estimated by doing 1000 bootstrap replicates.

The maximum-likelihood analyses were based on the unweighted, combined dataset using a general timereversible model for nucleotide substitutions proposed by the likelihood-ratio test in Modeltest (Posada and Crandall 1998). The GTR $+\mathrm{I}+\Gamma$ model uses six types of substitutions and estimates the proportions of invariable sites and the shape parameter (alpha) of the gamma distribution for evolutionary rate heterogeneity. Bayesian inference was calculated with MRBAYES 2.01, using the Markov chain Monte Carlo method (Huelsenbeck et al. 2001). A total of 400,000 generations were run. Stabilisation in the likelihood scores was reached after about 100,000 generations after which every hundred tree was saved. Posterior probabilities for clades were estimated from a majority-rule consensus tree calculated in PAuP* based on all the saved trees. A maximumlikelihood analysis was also performed on the taxonomically more inclusive cytochrome $b$ data set.

\section{Biogeographical analysis}

Molecular analyses of the oscine passerines give strong support to an east Gondwanan origin of the group (Sibley and Ahlquist 1990, Barker et al. 2002, Ericson et al. 2002b, 2003). To test if our phylogeny is consistent with such an origin of the corvid clade we made an analysis of the ancestral distribution within the phylogeny. To reconstruct the ancestral distribution we used the dispersal-vicariance (DIVA) algorithm (Ronquist 1996, 1997). The DIVA analysis is an event-based approach that makes no assumptions about a general area relationship. Hence, there are no area configuration constraints on the ancient distributions. This means that the DIVA analysis allows for geological events to have generated and eliminated dispersal barriers. Therefore the DIVA analysis can handle both hierarchical and reticulate area relationships within the phylogeny.

The DIVA analysis can only handle fully bifurcate trees, and it requires that the distribution of extant species and their ancestors is described from a set of exclusive areas. Speciation is allowed to take place either within unit areas or as vicariance events separating the continuous range of a mother species into two mutually exclusive ranges of daughter species. Neither of these processes changes the set of unit areas that are used. In contrast dispersal into new areas expands the set of areas while at extinction unit areas are deleted. The DIVA algorithm, allocates a "cost" to dispersal and extinction events that entail a change in the set of unit areas and produces an optimal solution for the ancestral distribution based on the phylogeny of extant species and their distribution. Given the information contained in the distribution of extant species, the optimal solution identifies the ancestral distribution as a unique area or several unit areas as the location for branching events in the phylogeny.

Selection of the set of unit areas is crucial to the DIVA analysis. Herein we choose to divide the distribution of the extant species in seven unit areas to reflect the current dispersal barriers and habitat distributions (Table 3). Some of these have well defined borders, while in other cases the definition has to be somewhat arbitrary. Given the somewhat arbitrary delimitation of ranges we considered a species as present in an area only if its distribution there encompassed more than $5 \%$ of its range.

\section{Results}

\section{The combined data set - two nuclear introns and the mitochondrial cytochrome $b$}

Molecular variation and analyses of saturation. The unweighted cytochrome $b$ data set consisted of 397 $(43 \%)$ characters that vary between taxa of which 298 $(32 \%)$ were phylogenetically informative. After the exclusion of transitions at third codon positions (see below), the cytochrome $b$ data set consisted of 397 (43\%) variable characters of which $250(27 \%)$ were phylogen- 
Table 3. Definition of the set of unit areas used in the dispersal-vicariance (DIVA) biogeographical analysis.

\begin{tabular}{ll}
\hline Biogeographic region & \multicolumn{1}{c}{ Definition } \\
\hline Australian & Australian continent and Tasmania, New Guinea \\
Oriental & Indonesia, south and southeast lowland China, Indochina, India, Bangladesh, Pakistan, Nepal \\
Western and Central Asia & $\begin{array}{l}\text { Highland China, Mongolia and west to Red Sea/Mediterranean Sea } \\
\text { Afthiopian }\end{array}$ \\
North Asia & Asia (western border of Ural mountains) north of western and Central Asia, and the Oriental region \\
Western Palearctic & Europe (eastern border Ural mountains), North Africa \\
New World & North and South America \\
\hline
\end{tabular}

etically informative. The corresponding values for myoglobin intron 2 were $113(16 \%)$ variable characters of which $34(5 \%)$ were phylogenetically informative, and for $\beta$-fibrinogen intron 7, $236(25 \%)$ and $66(7 \%)$, respectively.

Nucleotide substitutions in cytochrome $b$ were saturated for transitions at third codon positions, as indicated when plotted against the observed sequence distances of both the myoglobin and $\beta$-fibrinogen data set (Fig. 1). Transitions at third codon positions in cytochrome $b$ thus were excluded from the parsimony analyses (but not from the maximum-likelihood analyses).

Plotting nuclear substitutions observed in the two nuclear introns against each other indicates that the $\beta$-fibrinogen intron evolves about $40 \%$ faster than the myoglobin intron (Fig. 2). As evident from the pairwise
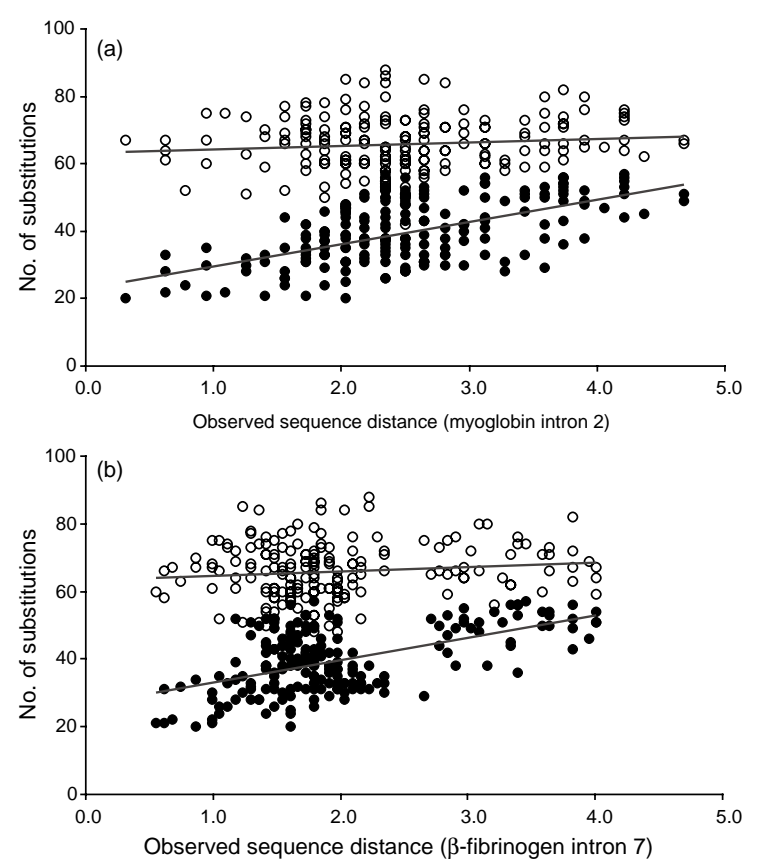

Fig. 1. Saturation plots of cytochrome $b$ substitutions at third positions of the codon, against the observed pairwise sequence distances of a) the myoglobin gene, and b) the $\beta$-fibrinogen gene. The plots shows that transitions (open circles) in the cytochrome $b$ sequences clearly reach saturation (also indicated by the almost horizontal regression line), whereas transversions (closed circles) do not. sequence divergences observed for the three genes across taxa, both nuclear introns evolve considerably slower than does cytochrome $b$.

Pairwise sequence distances. The observed pairwise sequence distances for the unweighted cytochrome $b$ data set range from 9.8\% (Corvus monedula - Corvus frugilegus) to $18.6 \%$ (Perisoreus - Lanius). Among ingroup taxa the maximum divergence is $17.2 \%$ (Garrulus - Pyrrhocorax); Table 4). Pairwise sequence distances in myoglobin intron 2 range between $0.3 \%$ (Cyanocitta - Gymnorhinus) and 4.7\% (Aphelocoma Epimachus, and Pica - Lanius), with the maximum observed distance among ingroup taxa is 3.7\% (Pica Aphelocoma). For intron 7 of $\beta$-fibrinogen the distances range from 1.1\% (Calocitta - Cyanocorax) to $8.0 \%$ (Corvus monedula - Lanius, Pica - Lanius, and Epimachus - Lanius). The maximum distance among ingroup taxa is 5.3\% (Perisoreus - Pica); Table 5).

Phylogenetic results. The general topologies of the phylogenetic trees obtained in the parsimony and maximum-likelihood analyses of the combined dataset agree well (Fig. 3A and B). Note that the weighted data set, with 3 rd position transitions in cytochrome $b$ excluded, was used in the parsimony analysis (but not in the maximum-likelihood analysis). The topologies can be summarised as follows (bootstrap support values for the parsimony analysis and posterior probabilities from the Bayesian analysis, respectively, are given in brackets): 1) the family Corvidae is recovered as monophyletic (MP: 100\%, Bayesian: 100\%), 2) Pyrrhocorax and Temnurus

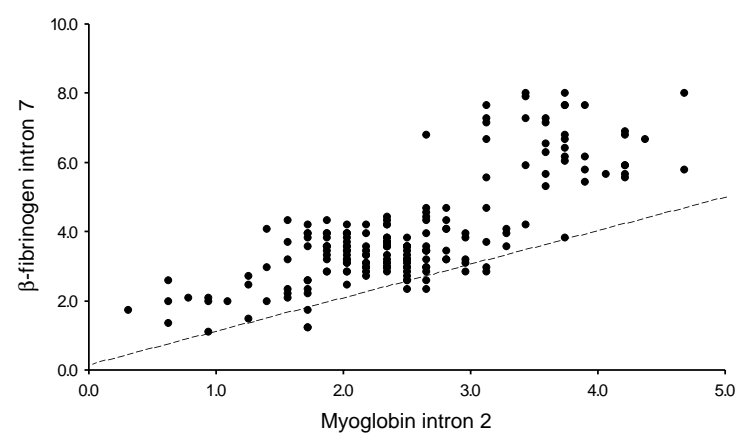

Fig. 2. Pairwise sequence distances observed in the two nuclear introns are plotted against each other. The line shows the 1:1 ratio, which gives an indication of a faster mutation rate in $\beta$ fibrinogen than in myoglobin. 
Table 4. Pairwise. uncorrected sequence divergencies (p-distances) for the unweighted cytochrome $b$ dataset (below diagonal). and for the same dataset but with tranversions only at third codon positions (above diagonal).

\begin{tabular}{|c|c|c|c|c|c|c|c|c|c|c|c|c|c|c|c|c|c|c|c|c|}
\hline & $\begin{array}{l}\text { Aphelo- } \\
\text { coma }\end{array}$ & $\begin{array}{l}\text { Calo- } \\
\text { citta }\end{array}$ & Cissa & $\begin{array}{l}\text { Corvus } \\
\text { frug. }\end{array}$ & $\begin{array}{l}\text { Corvus } \\
\text { mon. }\end{array}$ & $\begin{array}{l}\text { Cyano- } \\
\text { citta }\end{array}$ & $\begin{array}{l}\text { Cyano } \\
\text { corax }\end{array}$ & $\begin{array}{c}\text { Cyano } \\
\text { pica }\end{array}$ & $\begin{array}{l}\text { Garr- } \\
\text { ulus }\end{array}$ & $\begin{array}{l}\text { Gymno- } \\
\text { rhinus }\end{array}$ & $\begin{array}{l}\text { Periso- } \\
\text { reus }\end{array}$ & Pica & $\begin{array}{l}\text { Nuci- } \\
\text { fraga }\end{array}$ & Podoces & $\begin{array}{c}\text { Pyrrho- } \\
\text { corax }\end{array}$ & $\begin{array}{l}\text { Ptilost- } \\
\text { omus }\end{array}$ & $\begin{array}{l}\text { Temn- } \\
\text { urus }\end{array}$ & $\begin{array}{l}\text { Uro- } \\
\text { cissa }\end{array}$ & $\begin{array}{l}\text { Epima- } \\
\text { chus }\end{array}$ & Lanius \\
\hline Aphelocoma & & 7.47 & 8.55 & 6.60 & 6.60 & 5.41 & 6.93 & 7.27 & 7.68 & 4.98 & 7.47 & 6.49 & 7.14 & 8.13 & 9.20 & 6.93 & 6.91 & 8.01 & 8.87 & 10.93 \\
\hline Calocitta & 14.37 & & 9.74 & & 8.23 & 7.36 & 5.19 & 8.25 & 9.3 & 6.49 & 8.5 & 8.77 & 8.33 & & 10.93 & 8.44 & & 9.20 & 9.09 & 10.50 \\
\hline Cissa & 16.07 & 15.65 & & 7.14 & 6.82 & 8.01 & 9.09 & 6.95 & 8.33 & 8.44 & 6.93 & 6.39 & 6.60 & 6.2 & 8.44 & 6.60 & 7.76 & 5.74 & 8.55 & 10.17 \\
\hline $\begin{array}{l}\text { Corvus } \\
\quad \text { frugilegus }\end{array}$ & 13.94 & 13.51 & 13.51 & & 3.90 & 5.63 & 7.79 & 7.27 & 5.84 & 5.84 & 5.95 & 4.87 & 4.22 & 5. & 8.12 & 5.09 & 6.49 & 6.28 & 8.33 & 8.87 \\
\hline $\begin{array}{l}\text { Corvus } \\
\text { monedula }\end{array}$ & 13.66 & 15.36 & 12.66 & 9.82 & & 5.41 & 7.58 & 6.62 & 5.74 & 5.52 & 5.84 & 4.76 & 4.44 & 5.53 & 7.58 & 5.09 & 7.05 & 6.49 & 8.01 & 9.52 \\
\hline Cyanocitta & 13.23 & 13.66 & 15.65 & 12.80 & 11.66 & & 6.06 & 7.49 & 7.90 & 4.00 & 6.60 & 6.60 & 6.39 & 6.2 & 8.33 & 5.95 & 6.91 & 7.36 & 7.25 & 10.50 \\
\hline Cyanocorax & 13.51 & 1.38 & 16.64 & 13.66 & 14.94 & 13.51 & & 8.69 & 8.55 & 5.74 & 8.44 & 8.33 & 7.90 & 8. & 9.74 & 8.01 & 9.31 & 8.87 & 8.33 & 10.39 \\
\hline Cyanopica & 3.51 & 14.51 & 13.23 & 13.8 & 12.66 & 14.22 & 15.79 & & 8.47 & 6.73 & 6.6 & 5.54 & 6.30 & 6. & 8.79 & 6.3 & 7.08 & 7.60 & 8.47 & 9.55 \\
\hline Garrulus & 14.79 & 16.22 & 15.08 & 12.94 & 12.66 & 15.79 & 17.07 & 16.36 & & 7.36 & 7.25 & 6.39 & 6.49 & 7. & 8.87 & 6.49 & 7.48 & 7.14 & 8.66 & 9.63 \\
\hline Gymnorhinus & 12.23 & 13.66 & 16.93 & 13.0 & 1. & 11.38 & 12.23 & 13.37 & 15.50 & & 6.49 & 6.17 & 6.28 & & 8. & 6. & 7.05 & 7.58 & 6.93 & 9.85 \\
\hline Perisoreus & 15.65 & 14.08 & 14.08 & 13.09 & 12.66 & 14.79 & 16.07 & 14.65 & 15.79 & 15.50 & & 5.41 & 5.84 & 5. & 7.3 & 5.6 & 6.49 & 5.74 & 8.87 & 10.17 \\
\hline Pica & 52 & .22 & 12.38 & 1 & & 14.22 & 15.08 & 12.38 & 13.51 & 13.94 & 13.37 & & 4.98 & 5. & 7. & 4. & 6.63 & 6.82 & 7.79 & 9.63 \\
\hline Nucifraga & 14.65 & 14.37 & 13.80 & 11.95 & 12.23 & 13.37 & 14.94 & 14.65 & 14.65 & 14.37 & 15.36 & 12.66 & & 6.18 & 7.9 & 5.19 & 6.35 & 6.39 & 8.44 & 9.20 \\
\hline & 7 & 36 & 15.50 & 1 & & & 16.79 & 14.08 & 15.93 & 15.65 & & 13.23 & 14.37 & & 8.78 & 4.8 & 8.19 & 6.39 & & 9.86 \\
\hline Pyrrhocorax & 15.93 & 17.07 & 16.22 & 15.22 & 14.37 & 14.51 & 16.36 & 14.94 & 17.21 & 15.08 & 15.79 & 14.94 & 15.36 & 16.79 & & 8.44 & 5.64 & 7.79 & 8.98 & 10.06 \\
\hline Ptilostomus & 15.22 & 1 & 12.80 & 13.09 & & 13.37 & 15.79 & 12.52 & 13.66 & 13 & & 10.81 & 12.66 & & 15. & & 6.49 & 6.28 & & 10.17 \\
\hline Temn & 12.94 & 14.79 & 15.36 & 14.08 & 13.94 & 14.08 & 16.36 & 14.37 & 16.07 & 14.79 & 14.65 & 14.94 & 15.22 & & 12.3 & 14.65 & & 6.21 & 8.89 & 9.59 \\
\hline Urociss & 15.65 & 14.79 & 12.66 & 12.23 & 13.94 & 14.79 & 15.65 & 15.08 & 14.65 & 14.08 & 12.66 & 13.37 & 14.37 & & 15.36 & 13.51 & 14. & & 8.12 & 9.20 \\
\hline Epin & 15.93 & 15.65 & 15.50 & 15.6 & 15.7 & 15.93 & 16.07 & 15.08 & 17.21 & 16.36 & 16.79 & 14.65 & 16.64 & 17 & 17.07 & 14.94 & 17.35 & 13.66 & & 9.31 \\
\hline Lanius & 18.07 & 18.21 & 17.92 & 15.36 & 15.50 & 16.50 & 17.78 & 16.07 & 16.07 & 16.07 & 18.63 & 15.93 & 16.36 & 17.35 & 16.22 & 16.64 & 17.21 & 16.22 & 16.36 & \\
\hline
\end{tabular}


Table 5. Pairwise, uncorrected sequence divergencies (p-distances) for myoglobon intron 2 (below diagonal) and $\beta$-fibrinogen intron 7 (above diagonal).

\begin{tabular}{|c|c|c|c|c|c|c|c|c|c|c|c|c|c|c|c|c|c|c|c|c|}
\hline & $\begin{array}{l}\text { Aphel- } \\
\text { ocoma }\end{array}$ & $\begin{array}{l}\text { Calo- } \\
\text { citta }\end{array}$ & Cissa & $\begin{array}{l}\text { Corvu- } \\
\text { sfru }\end{array}$ & $\begin{array}{l}\text { Corvu- } \\
\text { smon }\end{array}$ & $\begin{array}{l}\text { Cyano- } \\
\text { citta }\end{array}$ & $\begin{array}{l}\text { Cyano- } \\
\text { corax }\end{array}$ & $\begin{array}{l}\text { Cyano- } \\
\text { pica }\end{array}$ & $\begin{array}{l}\text { Garr- } \\
\text { ulus }\end{array}$ & $\begin{array}{l}\text { Gymno- } \\
\text { rhinu }\end{array}$ & $\begin{array}{l}\text { Periso- } \\
\text { reus }\end{array}$ & Pica & $\begin{array}{l}\text { Nuci- } \\
\text { fraga }\end{array}$ & $\begin{array}{l}\text { Podo- } \\
\text { ces }\end{array}$ & $\begin{array}{l}\text { Pyrrh- } \\
\text { ocora }\end{array}$ & $\begin{array}{l}\text { Ptilos- } \\
\text { tomu }\end{array}$ & $\begin{array}{l}\text { Temn- } \\
\text { urus }\end{array}$ & $\begin{array}{l}\text { Uroc- } \\
\text { issa }\end{array}$ & $\begin{array}{l}\text { Epima- } \\
\text { chus }\end{array}$ & Lanius \\
\hline Calocitta & 1.72 & & 3.58 & 3.58 & 3.95 & 2.59 & 1.11 & 2.96 & 3.33 & 2.10 & 3.95 & 3.95 & 3.58 & 3.21 & 3.46 & 3.21 & 3.46 & 3.83 & 5.93 & 6.79 \\
\hline Cissa & 2.81 & 2.34 & & 3.95 & 4.32 & 3.95 & 2.96 & 3.09 & 3.83 & 3.46 & 4.20 & 4.32 & 3.95 & 3.58 & 3.58 & 3.58 & 2.84 & 1.98 & & 7.28 \\
\hline Corvusfru & 2.96 & 2.50 & 2.03 & & 2.10 & 3.95 & 2.96 & 3.33 & 2.84 & 3.46 & 4.69 & 3.09 & 1.98 & 2.59 & 3.58 & 2.35 & 3.58 & 4.20 & 5.93 & 7.65 \\
\hline Corvusmon & 2.50 & 2.03 & 1.56 & 0.78 & & 4.07 & 3.33 & 3.46 & 2.96 & 3.58 & 4.32 & 3.21 & 1.36 & 2.72 & 3.95 & 2.47 & 3.95 & 4.32 & 6.17 & 8.02 \\
\hline Cyanocitta & 1.40 & 0.62 & 1.72 & 1.87 & 1.40 & & 1.98 & 3.33 & 3.70 & 1.73 & 4.20 & 4.57 & 3.95 & 3.58 & 3.83 & 3.58 & 3.83 & 4.20 & 6.30 & 7.65 \\
\hline Cyanocorax & 1.72 & 0.94 & 2.34 & 2.50 & 2.03 & 0.94 & & 2.35 & 2.72 & 1.48 & 3.46 & 3.58 & 2.96 & 2.59 & 2.84 & 2.59 & 2.84 & 3.21 & 5.56 & 6.67 \\
\hline Cyanopica & 2.65 & 2.50 & 2.03 & 2.50 & 1.87 & 1.87 & 2.50 & & 3.09 & 2.84 & 3.09 & 3.95 & 3.09 & 2.96 & 2.84 & 2.96 & 2.72 & 3.58 & 5.43 & 6.54 \\
\hline Garrulus & 2.65 & 2.18 & 1.72 & 1.87 & 1.40 & 1.56 & 2.18 & 2.18 & & 3.21 & 4.44 & 3.46 & 2.59 & 2.47 & 3.33 & 2.22 & 3.21 & 3.70 & 6.17 & 7.16 \\
\hline Gymnorhinu & 1.72 & 0.94 & 2.03 & 2.18 & 1.72 & 0.31 & 1.25 & 2.18 & 1.87 & & 3.70 & 3.83 & 3.46 & 2.84 & 3.09 & 3.09 & 3.33 & 3.70 & 5.80 & 7.16 \\
\hline Perisoreus & 3.12 & 2.65 & 2.34 & 2.81 & 2.34 & 2.03 & 2.65 & 2.50 & 2.34 & 2.34 & & 5.31 & 4.44 & 4.07 & 3.83 & 4.32 & 4.07 & 4.69 & 6.79 & 7.65 \\
\hline Pica & 3.74 & 2.96 & 2.81 & 2.03 & 1.56 & 2.65 & 3.28 & 3.28 & 2.65 & 2.96 & 3.59 & & 2.84 & 2.59 & 4.20 & 2.96 & 4.07 & 4.69 & 6.67 & 8.02 \\
\hline Nucifraga & 2.81 & 2.34 & 1.87 & 1.09 & 0.62 & 1.72 & 2.34 & 2.34 & 1.72 & 2.03 & 2.65 & 1.87 & & 2.35 & 3.58 & 2.10 & 3.58 & 4.20 & 6.05 & 7.65 \\
\hline Podoces & 2.96 & 2.50 & 2.03 & 1.72 & 1.25 & 1.87 & 2.50 & 2.18 & 2.03 & 2.03 & 2.81 & $\begin{array}{l}1.01 \\
2.50\end{array}$ & 1.56 & & 2.96 & 2.22 & 2.96 & 3.70 & 5.68 & 7.28 \\
\hline Pyrrhocora & 3.12 & 2.65 & 1.87 & 2.65 & 2.18 & 2.03 & 2.65 & 2.34 & 2.34 & 2.34 & 2.34 & 3.43 & 2.50 & 2.65 & & 3.21 & 3.21 & 3.58 & 5.56 & 6.67 \\
\hline Ptilostomu & 3.12 & 2.50 & 1.87 & 1.72 & 1.25 & 2.03 & 2.65 & 2.34 & 1.72 & 2.18 & 2.65 & 2.34 & 1.56 & 1.56 & 2.50 & & 3.21 & 3.83 & 5.68 & 7.28 \\
\hline Temmurus & 2.96 & 2.50 & 2.03 & 2.50 & 2.03 & 1.87 & 2.50 & 2.50 & 2.50 & 2.18 & 2.81 & 3.28 & 2.34 & 2.18 & 2.03 & 2.65 & & 3.21 & 5.68 & 6.79 \\
\hline Urocissa & 2.81 & 2.34 & 0.62 & 2.34 & 1.87 & 1.72 & 2.34 & 2.34 & 2.34 & 2.03 & 2.65 & 3.12 & 2.18 & 2.34 & 2.18 & 2.50 & 2.03 & & 6.42 & 7.90 \\
\hline Epimachus & 4.68 & 4.21 & 3.43 & 4.21 & 3.74 & 3.59 & 4.21 & 3.90 & 3.90 & 3.90 & 4.21 & 4.37 & 3.74 & 4.21 & 3.12 & 4.06 & 3.59 & 3.74 & & 8.02 \\
\hline Lanius & 4.21 & 3.74 & 3.12 & 3.90 & 3.43 & 3.12 & 3.74 & 3.59 & 3.59 & 3.12 & 3.74 & 4.68 & 3.74 & 3.43 & 3.12 & 3.59 & 2.65 & 3.43 & 3.74 & \\
\hline
\end{tabular}


(a) Maximum-likelihood

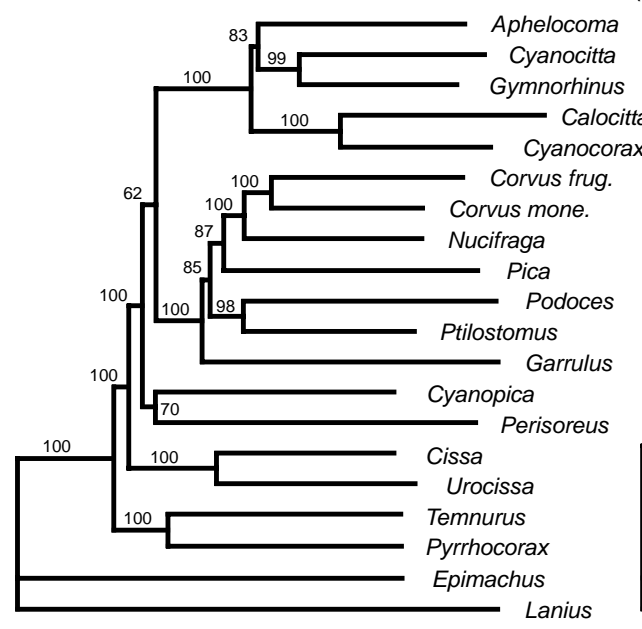

(b) Parsimony

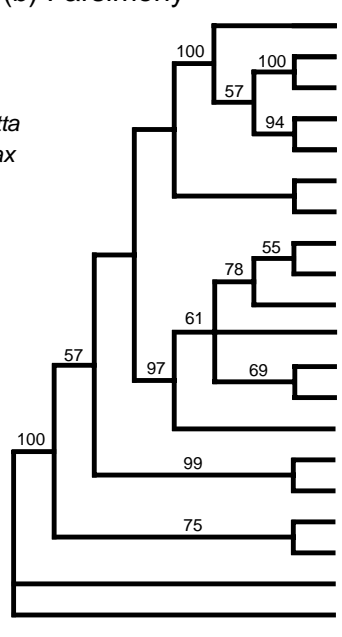

Aphelocoma

Calocitta

Cyanocorax

Cyanocitta

Gymnorhinus

Cyanopica

Perisoreus

Corvus frug.

Corvus mone.

Nucifraga

Pica

Podoces

Ptilostomus

Garrulus

Cissa.

Urocissa

Temnurus

Pyrrhocorax

Epimachus

Lanius
Fig. 3. Phylogenetic trees of the three genes (cytochrome $b$, myoglobin and $\beta$ -

fibrinogen) combined resulting from a maximumlikelihood analysis (left) and a parsimony analysis (right).

The maximum-likelihood tree shows the best-fit tree $(-\ln$ likelihood $=12413.62$ ). The numbers indicated on the branches are posterior probabilities $(>50 \%)$ estimated from the Bayesian inference analysis. The parsimony tree is a strict consensus tree based on the two shortest trees (length 1092, C.I: 0.42, R.I: 0.45) with nodal support values calculated by 1000 bootstrap replicates. fall outside a clade consisting of all other ingroup taxa (MP: $57 \%$, Bayesian: $100 \%$ ), 3) further up in the tree, Cissa and Urocissa form a clade that is the sister group to the remaining ingroup taxa (MP: this node is present in the strict consensus tree but receives no bootstrap support, Bayesian: 100\%), 4) the New World jays (Aphelocoma, Calocitta, Cyanocorax, Cyanocitta and Gymnorhinus) are monophyletic (MP: 100\%, Bayesian: $100 \%$ ), 5) the genera Corvus, Garrulus, Nucifraga, Pica, Podoces, and Ptilostomus form a clade (MP: 97\%, Bayesian: 100\%), and 6) Cyanopica and Perisoreus may be sister taxa (MP: the clade occurs in the strict consensus tree without bootstrap support, Bayesian: $70 \%$ ), but their positions in relation to other corvid genera cannot be conclusively determined.

Within the clade of New World jays, Calocitta groups strongly with Cyanocorax (MP: 100\%, Bayesian: 100\%) in the analyses of the combined data set, as does Cyanocitta with Gymnorhinus (MP: 94\%, Bayesian: 99\%). Aphelocoma is positioned basal of these four genera, but this arrangement receives only moderate support (MP: 57\%, Bayesian: 83\%).

The two Corvus representatives group together (MP: $55 \%$, Bayesian: $100 \%$ ), with Nucifraga outside these (MP: 78\%, Bayesian: 100\%). A clade with Podoces and Ptilostomus also receives high support (MP: 69\%, Bayesian: 98\%). The maximum-likelihood analysis places Pica as the next taxon outside these (with $87 \%$ posterior probability in the Bayesian analysis) but the parsimony analyses is ambiguous on this point. In both analysis Garrulus is the basal-most member of this clade of Eurasian and African taxa although the support for this is moderate (MP: $61 \%$, Bayesian: $85 \%$ ).

The resolution of the individual gene trees is low, with few nodes receiving bootstrap support (Fig. 4). The topologies of the individual gene trees are congruent with most of the general phylogenetic patterns found in the analysis of the combined data set, or at least alternative relationships do no receive a bootstrap support exceeding $50 \%$. The single exception is that in the $\beta$-fibrinogen tree where Temnurus groups with the Cissa/Urocissa clade on the exclusion of Pyrrhocorax, an arrangement that receives $79 \%$ bootstrap support.

\section{The taxonomically expanded cytochrome $b$ data set}

The maximum-likelihood and Bayesian analyses of the taxonomically more inclusive, cytochome $b$ data set generally corroborate the results of the combined nuclear and mitochondrial genes (Fig. 5). The genera Crypsirina, Dendrocitta and Platysmurus group with Temnurus, and they form, together with the two species of Pyrrhocorax, the sister group of all other corvids in the maximum-likelihood analysis. However, in the Bayesian analysis of the cytochrome $b$ data set Pyrrhocorax is positioned in the most basal position, with the Temnurus-group as the next branch up in the tree. In both analyses Cissa and Urocissa group together and are placed as the sister taxon to all other corvids (except Pyrrhocorax and the Temnurus-group).

Above this node are two clades that are also recognised in the combined nuclear and mitochondrial data set. A long branch in the maximum-likelihood tree leads to the first of these clades, the New World jays, and the monophyly of this group receive $100 \%$ posterior probability in the Bayesian analysis. The second clade unites a group of mostly Eurasian and African taxa that do not yield support exceeding $50 \%$ in the Bayesian analysis. The African Zavattariornis, of which no fresh material was available, evidently belong to this group, which also includes the genera Corvus, Garrulus, Nucifraga, Pica, Podoces, and Ptilostomus. The short internodes between 
Fig. 4. Gene trees calculated in parsimony analyses of DNA sequences obtained from the (a) cytochrome $b$,

(b) $\beta$-fibrinogen, and (c) myoglobin genes. The gene trees are strict consensus trees based on six original trees (length 639 , C.I: 0.35 , R.I: 0.36 ) for cytochrome $b, 292$ original trees for $\beta$-fibrinogen (length 292, C.I: 0.65, R.I: 0.71), and 288 original trees (length 144, C.I: 0.65 , R.I: 0.74 ) for myoglobin, respectively. Support values were obtained from 1000 bootstrap replicates. (a) Cytochrome b



(b) $\beta$-fibrinogen

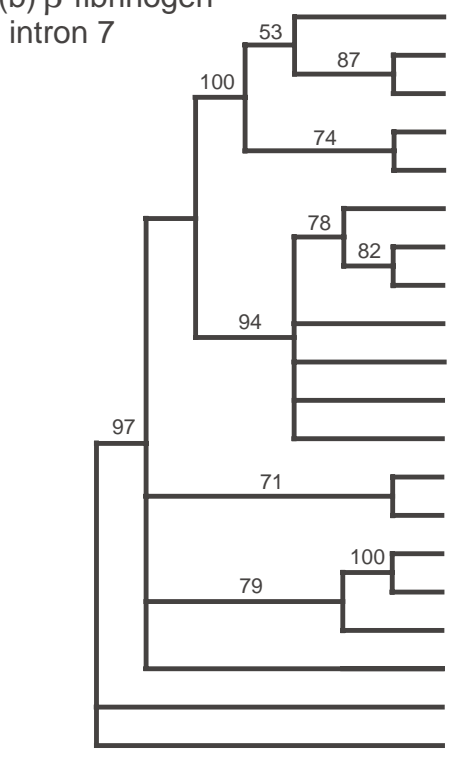

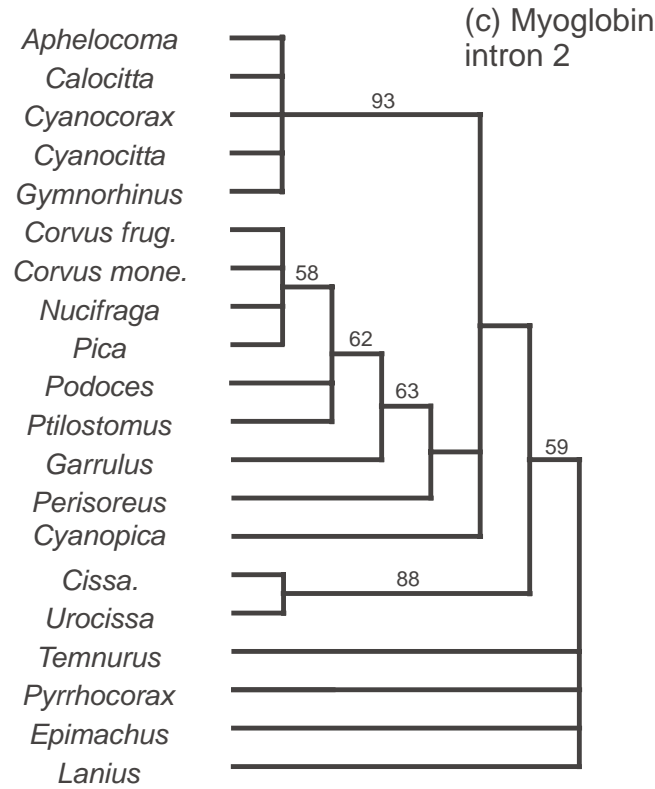

these taxa in the maximum-likelihood tree cast doubts about the basal relationships among them. As in the analyses of the combined nuclear and mitochondrial data set, Cyanopica and Perisoreus weakly group together. The precise relations of these taxa to other corvids are obscure also with the cytochrome $b$ data set.

\section{Ancestral distributions}

The outcome of the DIVA analysis was unambiguous in identifying the Oriental region (as defined in Table 3), as the area of ancestral corvid radiations. All four basal nodes in the corvid phylogeny based on maximum likelihood for the combined data for cytochrome b, myoglobin, and $\beta$-fibrinogen (Fig. 3a) were unambiguously identified as of Oriental origin. The position of the CyanopicalPerisoreus branch receives weak support in our analysis. In line with the recommendation for such situations (Ronquist 1997), we ran separate analyses with the alternate positions for this branch in our phylogeny. Shifting the position of the Cyanopical Perisoreus branch did, however, not alter the outcome of the DIVA analysis. 


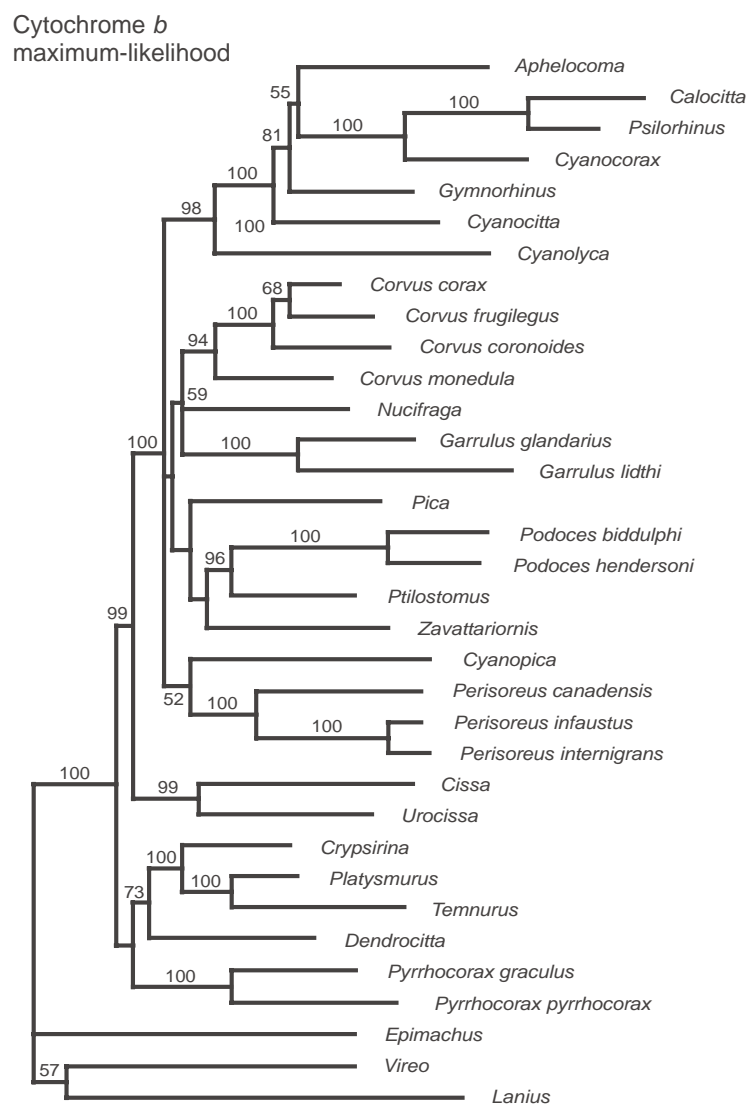

Fig. 5. Maximum-likelihood tree calculated for cytochome $b$ data obtained from the taxonomically more inclusive data set. The numbers indicated on the branches are posterior probabilities $(>50 \%)$ estimated from the Bayesian inference analysis.

\section{Discussion}

The ancestor of the oscine passerines, to which the Corvidae belongs, appears to have been isolated on the Australo-Papuan tectonic plate when this split from Antarctica in the early Tertiary (Ericson et al. 2002b, 2003). The subsequent spread of oscines into other parts of the world began when the Australo-Papuan plate came close enough to Asia to allow dispersals. It is unknown how many successful dispersal events of oscines have taken place but the family Corvidae belongs to these. It is intriguing that the oldest branches of corvids, as identified in the present study, include taxa that almost all are geographically confined to the southeastern parts of Asia, i.e., the area to which the corvid ancestor presumably first arrived from the Australo-Papuan region. The genera Crypsirina, Dendrocitta, Platysmurus, Temnurus, Cissa and Urocissa all inhabit tropical and subtropical forests in Southeast Asia and nearby areas. Pyrrhocorax is an exception to this pattern in being distributed in mountain areas from the Himalayas to western Europe. An analysis of osteological and other morphological characters suggested Pyr- rhocorax to be closely related to Corvus and Nucifraga (Hope 1989), which conform to the traditional opinion about the relationships of this taxon. Unexpectedly, Cibois and Pasquet (1999) based on an analysis of cytochrome $b$ data found Pyrrhocorax to be basal among the corvids. In our analysis, this was confirmed not only by the cytochrome $b$ data, but by the myoglobin and $\beta$-fibrinogen data as well.

Despite the Australo-Papuan origin of the oscine radiation, there is among genera belonging to the basal branches of the corvids a complete lack of species with a distribution on Australia proper. The almost total prevalence of species with forest-living habits among the basal clades sits well with the Corvidae having radiated only after the exodus of an ancestral passerine from Australia. There seems to be little reason to doubt that the Corvidae originated from forest living ancestors. Its closest relatives (e.g., Paradisaeidae, Oriolidae) are forest adapted, and the basal groups within the Corvidae consist almost exclusively of forest living species, once again with the exception of genus Pyrrhocorax. By the time that the oscines started to radiate extensively in late Oligocene and Miocene (Feduccia 1995), the early Tertiary rainforests of Australia had become largely replaced by more open savanna-like forests or under extreme conditions even by desert like conditions. Hence, by the time the Corvidae started to radiate the Australian continent had already become less suitable habitat for a forest adapted ancestor.

Later radiations of Corvidae seem to be associated with an adaptation to drier habitats allowing an expansion out of the Southeast Asian range into more open habitats and resulting in the current almost ubiquitous distribution. However, as a legacy of their origin the clades of later radiations contain taxa with a distribution encompassing southeast Asia (e.g., Cyanopica, Perisoreus internigrans, Garrulus lidthi, Pica pica). The adaptation to arid conditions is at its most extreme in the desert adapted Asian genus Podoces while the African genera Ptilostomus and Zavattariornis inhabit dry grassland. Within the "Old World" clade, Podoces and Ptilostomus unexpectedly grouped together, considering their different geographical distributions. This clade yields $98 \%$ posterior probability in the Bayesian analysis, but only $69 \%$ in the parsimony analysis. Within this clade the adaptation to truly arid conditions thus appears to be a single evolutionary event according to the phylogenetic analysis. The disjunct distribution of the extant species should then reflect later dispersal events coupled to further specialisation.

Soon after the initial radiation of corvids in the southeast Asian region, the ancestors to the New World jays spread to the Americas, presumably by following the trans-Beringian route. In North America, and later in South and Middle America, the New World jays underwent significant adaptive radiations. Unlike most 
Palearctic jays that are confined to forested areas, several New World jays inhabit open terrain. In the Old World most corvids living in open areas belong to the crows (e.g., Corvus) and the New World jays may have had little competition from these in the beginning. Today, the three genera Corvus, Perisoreus and Nucifraga occur in the Americas, but these all have their core-distribution in other parts of the world. These three groups presumably radiated in the Palearctic and later immigrated to the New World, while the magpies (Pica) appear to have speciated after immigration to the New World (Lee et al. 2003).

Monophyly of the New World jays is strongly supported herein and has been established based on DNA sequence data before (Espinosa de los Monteros and Cracraft 1997, Cibois and Pasquet 1999). The overall topology of the New World jay clade differs somewhat between the parsimony and likelihood analyses of the combined data set. In both analyses Cyanocitta groups with Gymnorhinus, and Calocitta with Cyanocorax. In the parsimony analysis Aphelocoma is basal to these four genera (57\% support), while it groups with the Cyanocitta-Gymnorhinus clade in the maximum-likelihood analysis (with $83 \%$ posterior probability in the Bayesian analysis). The latter topology agrees with that of Espinosa de los Monteros and Cracraft (1997) based on cytochrome $b$ sequences obtained from a larger number of New World jay species. Based on the finding that the Cyanocorax-Calocitta clade is basal in their phylogenetic tree, they hypothesized that the ancestor of the New World jays dispersed from Eurasia via Beringia to the Americas. The group later underwent a rapid radiation in South America giving rise to the Cyanocorax-Calocitta clade. A more recent, secondary radiation further north should then have given rise to the Cyanocitta-Gymnorhinus-Aphelocoma clade.

A widely held theory about the systematic relationships among jays postulates that the Palearctic jays (Garrulus and Perisoreus) form a monophyletic group together with the New World jays. This is not supported in the present analysis: Garrulus clearly is a member of a clade consisting of several Old World core-groups, while the systematic position of old world core in groups Perisoreus can not be conclusively determined. Furthermore, contra the suggestion made by Madge and Burn (1994), and in agreement with the results of Cibois and Pasquet (1999), our analyses do not support a close relationship between Garrulus and Perisoreus. Instead, Perisoreus seems to be closest to Cyanopica, and the clade of these two in turn form a trichotomy with the New World jays on one hand, and the large group of core-Old World taxa on the other. The short internodes in this part of the tree in general, and between the three major clades in particular, suggest a rather rapid cladogenesis.
Acknowledgements - We thank the Field Museum of Natural History (Chicago), Muséum National d'Histoire Naturelle (Paris), Swedish Museum of Natural History, and Burke Museum of Natural History and Culture (Seattle) for providing tissue. Martin Irestedt, Pia Eldenäs and Mari Källersjö provided help and advice in the laboratory. Andrew Cockburn, Eric Pasquet and Dario Zuccon are thanked for commenting on the manuscript. This work has been funded by the Swedish Research Council (grant no. 621-2001-2773 to P.E.) and the Swedish Museum of Natural History.

\section{References}

Amadon, D. 1944. The genera of Corvidae and their relationships. - Amer. Mus. Novit. 1251: 1-51.

A.O.U. 1998. Check-list of North American Birds. - American Ornithologists' Union, Washington, DC..

Barker, K. F., Barrowclough, G. F. and Groth, J. G. 2002. A phylogenetic analysis for passerine birds: taxonomic and biogeographic implications of an analysis of nuclear DNA sequence data. - Proc. R. Soc. Lond. B 269: 295-308.

Cibois, A. and Pasquet, E. 1999. Molecular analysis of the phylogeny of 11 genera of the Corvidae. - Ibis 141: 297306.

Cicero, C. and Johnson, N. K. 1998. Molecular phylogeny and ecological diversification in a clade of New World songbirds (genus Vireo). - Mol. Ecol. 7: 1359-1370.

Clench, M. H. 1985. Body pterylosis of Atrichornis, Menura, the 'corvid assemblage' and other possibly related passerines (Aves: Passeriformes). - Rec. Austral. Mus. 37: 115-142.

Cracraft, J. and Feinstein, J. 2000. What is not a bird of paradise? Molecular and morphological evidence places Macgregoria in the Meliphagidae and the Cnemophilinae near the base of the corvoid tree. - Proc. R. Soc. Lond. B 267: $233-241$.

Desjardins, P. and Morais, R. 1990. Sequence and gene organization of the chicken mitochondrial genome. - J. Mol. Biol. 212: 599-634.

Ericson, P. G. P. and Johansson, U. S. 2003. Phylogeny of Passerida (Aves: Passeriformes) based on nuclear and mitochondrial sequence data. - Mol. Phylogenet. Evol. 29: $126-138$.

Ericson, P. G. P., Christidis, L., Irestedt, M. and Norman, J. A. 2002a. Systematic affinities of the lyrebirds (Passeriformes: Menura), with a novel classification of the major groups of passerine birds. - Mol. Phylogenet. Evol. 25: 53-62.

Ericson, P. G. P., Christidis, L., Cooper, A., Irestedt, M., Jackson, J., Johansson, U. S. and Norman, J. A. 2002b. A Gondwanan origin of the passerine birds supported by DNA sequences of the endemic New Zealand wrens. - Proc. R. Soc. Lond. B 269: 435-441.

Ericson, P. G. P., Irestedt, M. and Johansson, U. S. 2003. Evolution, biogeography, and patterns of diversification in passerine birds. - J. Avian Biol. 34: 3-15.

Espinosa de los Monteros, A. and Cracraft, J. 1997. Intergeneric relationships of the new world jays inferred from cytochrome $b$ gene sequences. - Condor 99: 490-502.

Feduccia, A. 1995. Explosive evolution in Tertiary birds and mammals. - Science 267: 637-638.

Goodwin, D. 1976. Crows of the world. - British Museum (National History), London.

Härlid, A. and Arnason, U. 1999. Analyses of mitochondrial DNA nests ratite birds within the Neognathae-supporting a neotenous origin of ratite morphological characters. - Proc. R. Soc. Lond. B 266: 305-309.

Helm-Bychowski, K. and Cracraft, J. 1993. Recovering phylogenetic signal from DNA sequences: Relationships within the Corvine assemblage (Class Aves) as inferred from complete sequences of the mitochondrial DNA cytochrome- $b$ gene. - Mol. Biol. Evol. 10: 1196-1214. 
Hope, S. 1989. Phylogeny of the avian family Corvidae. - PhD dissertation, City Univ. New York, NY.

Huelsenbeck, J. P., Ronquist, F. and Hall, B. 2001. MrBayes: Bayesian inference of phylogeny. - Bioinformatics 17: 754755.

Irestedt, M., Fjeldså, J., Johansson, U. S. and Ericson, P. G. P. 2002. Systematic relationships and biogeography of the tracheophone suboscines (Aves: Passeriformes). - Mol. Phyl. Evol. 23: 499-512.

James, H. F., Ericson, P. G. P., Slikas, B., Lei, F.-M., Gill, F. B. and Olson, S. L. 2003. Pseudopodoces humilis, a misclassified terrestrial tit (Aves: Paridae) of the Tibetan Plateau: evolutionary consequences of shifting adaptive zones. - Ibis 145: $185-202$.

Kumar, S., Tamura, K. and Nei, M. 1993. MEGA: molecular evolutionary genetics analysis, version 1.02., Pennsylvania State Univ., University Park, PA.

Lee, S., Parr, C. S., Hwang, Y., Mindell, D. P. and Choe, J. C. 2003. Phylogeny of magpies (genus Pica) inferred from mtDNA data. - Mol. Phyl. Evol. 29: 250-257.

Madge, S. and Burn, H. 1994. Crows and jays: a guide to crows, jays and magpies of the world. - A and C Black Ltd, London.

Morony, J. J., Bock, W. J. and Farrand, J. 1975. Reference list of the birds of the world. - Amer. Mus. of Nat. Hist, New York, NY

Mundy, N. I., Unitt, P. and Woodruff, D. S. 1997. Skin from feet of museum specimens as a non-destructive source of DNA for avian genotyping. - Auk 114: 126-129.

Nunn, G. B. and Cracraft, J. 1996. Phylogenetic relationships among the major lineages of the birds-of-paradise (Paradisaeidae) using mitochondrial DNA gene sequences. - Mol. Phyl. Evol. 5: 445-459.
Posada, D. and Crandall, K. A. 1998. MODELTEST: testing the model of DNA substitution. - Bioinformatics 14: 817818.

Prychitko, T. M. and Moore, W. S. 1997. The utility of DNA sequences of an intron from the $\beta$-fibrinogen gene in phylogenetic analysis of woodpeckers (Aves: Picidae). - Mol. Phyl. Evol. 8: 193-204.

Prychitko, T. M. and Moore, W. S. 2000. Comparative evolution of the mitochondrial cytochrome $b$ gene and nuclear $\beta$ fibrinogen intron 7 in woodpeckers. - Mol. Biol. Evol. 17: $1101-1111$.

Ronquist, F. 1996. DIVA version 1.1 Computer program and manual available by anonymus FTP from Uppsala university (http://www.ebc.uu.se/systzoo/research/diva/diva.html).

Ronquist, F. 1997. Dispersal-vicariance analysis: a new approach to the quantification of historical biogeography. - Syst. Biol. 46: 195-203.

Saunders, M. A. and Edwards, S. V. 2000. Dynamics and phylogenetic implications of mtDNA control region sequences in New World jays (Aves: Corvidae). - J. Mol. Evol. 51: 97-109.

Sibley, C. G. and Ahlquist, J. E. 1990. Phylogeny and classification of birds.. - Yale University Press, New Haven, CT.

Sibley, C. G. and Monroe, B. L. Jr. 1990. Distribution and taxonomy of birds of the world. - Yale University Press, New Haven, CT.

Swofford, D. L. 1998. PAUP*: Phylogenetic analysis using pasimony (and other methods), version 4.0b10. - Sinauer, Sunderland, MA.

(Received 3 March 2004, revised 17 June 2004, accepted 7 July 2004.) 